Фармацевтична технологія, біофармація, гомеопатія Pharmaceutical technology, biopharmacy, homeopathy

Рекомендована д. фрармац. наук, профр. Т. Г. Калинюком УДК 615.262+616.594.14

DOI 10.11603/2312-0967.2018.1.8599

\title{
ДОСЛІДЖЕННЯ 3 РОЗРОБКИ ТЕХНОЛОГІЇ НАСТОЙКИ «СТИМУФІТ», ПРИЗНАЧЕНОЇ ДЛЯ ЗАСТОСУВАННЯ ПРИ ТЕЛОГЕНОВІЙ АЛОПЕЦІЇ
}

\author{
() М. І. Федоровська ${ }^{1}$, Н. П. Половко르, Н. С. Леочко ${ }^{1}$ \\ Івано-Франківський національний медичний університет ${ }^{1}$ \\ Національний фрармацевтичний університет, Харків \\ maryana@fedorovska.com
}

\begin{abstract}
Мета роботи. Розробка технології складної настойки «Стимуфріт», призначеної для нашкірного застосування при телогеновій алопеції.

Матеріали і методи. В якості лікарської рослинної сировини (ЛРС) використовували суміш листя кропиви дводомної - 50 г, листя шавлії лікарської - 30 г, листя каштана кінського - 20 г. Для розробки технології складної настойки обирали оптимальні параметри екстрагування, а саме: концентрація етанолу (20 \%, 40 \%, 70 \%), співвідношення сировини і готового продукту $(1: 5,1: 10,1: 15,1: 20)$, ступінь подрібнення сировини (подрібнена та непросіяна ЛРС, різні фрракції), час (6 год, 1 доба, 2 доби, 3 доби, 7 діб) та метод (мацерація, ремацерація, перколяція) екстракції. Критеріями оцінки були: вихід екстрактивних речовин та кількісний вміст гідроксикоричних кислот (ГКК).

Результати й обговорення. Як екстрагент обрано 40 \% етанол, який добре розчиняє основні біологічно активні речовини та безпечний для нашкірного застосування. Враховуючи концентрацію сухого залишку та ГКК в самій настойці, а також у перерахунку на суху сировину (есективність виснаження лРС), обґрунтовано технологію складної настойки, яку одержують із подрібненої та непросіяної суміші ЛРС у співвідношення 1:10 методом трикратної ремацерації протягом 3 діб.

Висновки. Визначені оптимальні технологічні параметри виготовлення складної настойки, а саме: концентрація етанолу - 40 \%, співвідношення ЛРС до готового продукту - 1:10, ступінь подрібнення сировини - подрібнена ціла ЛРС, час екстракції - не довше 3-х діб, метод екстрагування - ремацерація. Враховуючи отримані результати, розроблено технологічну схему виробництва складної настойки «Стимуфіт» у промислових умовах.
\end{abstract}

Ключові слова: телогенова алопеція; настойка; кропива дводомна; шавлія лікарська; каштан кінський; технологічні параметри.

Вступ. Перспективним напрямком наукових досліджень $€$ розробка вітчизняних фрітопрепаратів, що призначені для профілактики та лікування осіб з різними формами алопеції. Телогенова алопеція (ТА) це найбільш поширене дисузне облисіння у жінок репродуктивного віку, що зумовлене впливом на волосяний фролікул (ВФ) шкідливих провокуючих чинників (патології ендокринної системи, іноекційні захворювання, стресові стани, авітамінози тощо). Дія лікарських речовин у терапії ТА спрямована на посилення капілярного кровообігу та зміцнення судин, стимуляцію росту епітеліальних клітин ВФ, насичення мікроелементами та іншими поживними речовинами тканин шкіри, виявлення фунгістатичних властивостей проти грибка Malassezia ovale (зумовлює лупу) [1]. Для профрілактики та лікування ТА вітчизняний фрармацевтичний ринок пропонує лікарські препарати та біологічно активні добавки системного впливу (комплекси мікроелементів та вітамінів, препарати заліза, цинку, імуномодулятори, біогенні стимулятори) та природні чи синтетичні засоби для на- шкірного застосування (Аллотон, Капсіол, Фітовал, Міноксидил та ін.) [2].

Для посилення росту волосся традиційна та народна медицини використовує широкий асортимент таких лікарських рослин, як береза бородавчата, череда трироздільна, ромашка лікарська, каштан кінський, рускус колючий, гінкго дволопатеве, лопух звичайний, хміль звичайний, кропива дводомна, софора японська, аїр очеретяний, перець стручковий, шавлія лікарська, розмарин лікарський та ін. Вказані рослини містять різні групи біологічно активних речовин (БАР), а саме: дубильні речовини, фрлавоноїди (рутин, кверцетин), тритерпенові сапоніни (есцин, рускогенін), гідроксикоричні кислоти (кофрейна, хлорогенова), кумарини (ескулін), каротиноїди, хлорофріл, ефрірні олії, алкалоїди (капсицин), аліфратичні кислоти (мурашина, яблучна, лимонна) тощо [3, 4].

Необхідно зазначити, що асортимент лікарських рослинних засобів (ЛРЗ) з комплексною дією при згаданій патології на фрармацевтичному ринку України

ISSN 2312-0967. Фармацевтичний часопис. 2018. № 1 
обмежений. Отже, створення нового багатокомпонентного ЛР3 у формі складної настойки для профрілактики і терапії ТА з використанням доступної лікарської рослинної сировини (ЛРС) є актуальним завданням фрармацевтичної науки.

У процесі розробки складної настойки в попередніх дослідженнях ми обрали ЛРС, для якої характерні необхідні для ТА фрармакологічні властивості. Такою ЛРС є листя кропиви дводомної (містить аліфратичні та гідроксикоричні кислоти, фрлавоноїди, хлорофріл, кремнійорганічні сполуки, вітаміни C, E, B, $\mathrm{B}_{2}, \mathrm{~B}_{6}$, пантотенова і фролієва кислоти та ін.), листя шавлії лікарської (містить до 2,5 \% ефрірної олії, дитерпенову кислоту сальвін, дубильні речовини та ін.), листя каштана кінського (містить не менше 1\% фрлавоноїдів, каротиноїди тощо). БАР запропонованої ЛРС виявляють регенеруючі властивості, посилюють шкірний кровообіг, зменшують проникність і ламкість капілярів, надають антимікробну дію, живлять та покращують обмінні процеси в шкірі голови [5-8]. Для вибору кількісного співвідношення компонентів у фрітокомпозиції ми провели фрармакотерапевтичний та фрітохімічний дизайн ЛР3 з урахуванням внеску кожної ЛРС у кінцевий терапевтичний ефект відповідно до правил складання лікарських зборів. У результаті проведених досліджень запропоновано склад фрітокомпозиції на 100 г, а саме: листя кропиви дводомної - 50 г, листя шавлії лікарської 30 г, листя каштана кінського - 20 г.

Мета роботи - розробка технології складної настойки «Стимусіт», що призначена для нашкірного застосування при телогеновій алопеції.

Матеріали і методи. Для одержання настойки заготовляли листя кропиви дводомної (за ДФУ 2) та листя каштана кінського (ТУ 64-4-76-87 «Листья каштана конского обыкновенного» Російської Федерації) в період кінець травня - початок червня в Івано-Франківській області (с. Клузів, Тисминецький р-н; с. В. Струтинь, Рожнятівський р-н); листя шавлії лікарської - постачальник ЗАТ «Ліктрави», м. Житомир.

У процесі розробки технології ЛР3 обирали оптимальні параметри екстрагування фрітокомпозиції, а саме: концентрація етанолу (20 \%, 40 \%, 70 \%); співвідношення ЛРС і готового продукту $(1: 5,1: 10,1: 15$, 1:20); ступінь подрібнення ЛРС (зразок № 1 - подрібнена та непросіяна ЛРС, № 2 - ЛРС розміром 5 і більше мм, № 3 - ЛРС розміром 3-4 мм, № 4 - ЛРС 3 розміром 0-2 мм); час екстракції (6 год, 1 доба, 2 доби, 3 доби, 7 діб); метод екстракції (мацерація, ремацерація, перколяція). Критеріями оцінки були: вихід екстрактивних речовин (сухий залишок) та вміст гідроксикоричних кислот (ГКК).

Екстрактивні речовини визначали за ДФУ 2, п. 2.8.16 [7].

2 мл настойки поміщають у плоскодонну чашку діаметром близько 50 мм і заввишки близько 30 мм.
Фармацевтична технологія, біофармація, гомеопатія

Pharmaceutical technology, biopharmacy, homeopathy

Випарюють насухо на водяній бані та сушать у сушильній шафрі при температурі від 100 до $105^{\circ} \mathrm{C}$ протягом 3 годин. Охолоджують в ексикаторі над фоосорру (V) оксидом P і зважують. Результат виражають у вагових відсотках або у грамах на літр.

Вміст ГКК встановлювали за методикою ДФУ 2, том 3, «Кропиви листя», С. 358-359.

Випробовуваний розчин. 2 мл вихідного розчину поміщають у мірну колбу місткістю 25,0 мл, послідовно додають, перемішуючи після кожного додавання, 2 мл 0,5 М розчину кислоти хлористоводневої, 2 мл свіжоприготованого розчину 10 г натрію нітриту і 10 г натрію молібдату у 100 мл води, 2 мл розчину натрію гідроксиду розведеного, доводять об'єм розчину водою до позначки та перемішують.

Компенсаційний розчин. 2 мл вихідного розчину помішають у мірну колбу місткістю 25,0 мл, послідовно додають, перемішуючи після кожного додавання, 2 мл 0,5 М розчину кислоти хлористоводневої і 2 мл розчину натрію гідроксиду розведеного, доводять об'єм розчину водою до позначки та перемішують.

Відразу вимірюють оптичну густину випробовуваного розчину при довжині хвилі 525 нм у кюветі із товщиною шару 10 мм, використовуючи як розчин порівняння компенсаційний розчин. Вміст суми гідроксикоричних кислот у настойці, у перерахунку на кислоту хлорогенову, у відсотках, обчислюють за фрормулою:

$$
X=\frac{A \times 25}{188 \times 2},
$$

де X - концентрація ГКК, A - оптична густина випробовуваного розчину за довжини хвилі 525 нм; 25 - об'єм мірної колби, мл, 2 - об'єм піпетки, мл. Використовують питомий показник поглинання кислоти хлорогенової, що дорівнює 188.

Результати й обговорення. Враховуючи, що ЛКЗ передбачений для нашкірного застосування на волосистій частині голови, як екстрагент обрано 40 \% етанол. Екстрагент 3 вищою концентрацією негативно впливатиме на ліпідно-епідермальний бар'єр шкіри, а з нижчою - не забезпечуватиме повноти екстракції з ЛРС фрлавоноїдів, ефрірних олії, гідроксикоричних кислот.

У технології настойок важливим фрактором, який впливає на ступінь вивільнення БАР з ЛРС, $є$ співвідношення сировини до готового продукту. Тому для дослідження використовували зразки настойок в наступних співвідношеннях: 1:5, 1:10, 1:15, 1:20. Настойки готували стандартним методом мацерації на 40 \% етанолі, використовуючи подрібнену і непросіяну ЛРС. Результати визначення динаміки вилучення суми екстрактивних речовин та ГКК представлені в таблиці 1 та на рисунку 1.

Отримані дані засвідчують, що із зменшенням маси ЛРС на 100 мл готового продукту очікувано зменшується сумарна кількість екстрактивних речо-

ISSN 2312-0967. Pharmaceutical review. 2018. № 1 
Фармацевтична технологія, біофармація, гомеопатія Pharmaceutical technology, biopharmacy, homeopathy

Таблиця 1. Результати визначення сухого залишку та ГКК залежно від співвідношення ЛРС - готовий продукт

\begin{tabular}{|c|c|c|c|c|c|}
\hline \multirow{2}{*}{$\begin{array}{c}\text { Співвідношення } \\
\text { ЛРС-готовий } \\
\text { продукт }\end{array}$} & \multirow{2}{*}{$\begin{array}{c}\text { Кількість ЛРС } \\
\text { на } 100 \text { мл } \\
\text { настойки, г }\end{array}$} & \multicolumn{2}{|c|}{ Вміст екстрактивних речовин } & \multicolumn{2}{|c|}{ Вміст ГКК } \\
\hline & & $\begin{array}{c}\text { у } 100 \text { мл } \\
\text { настойки, \% }\end{array}$ & $\begin{array}{c}\text { у перерахунку } \\
\text { на суху ЛРС, \% }\end{array}$ & $\begin{array}{c}\text { у } 100 \text { мл } \\
\text { настойки, \% }\end{array}$ & $\begin{array}{l}\text { у перерахунку } \\
\text { на суху ЛРС, \% }\end{array}$ \\
\hline $1: 5$ & 20 & $2,66 \pm 0,040$ & $13,31 \pm 0,2$ & $0,0392 \pm 2 \cdot 10^{-4}$ & $0,196 \pm 0,001$ \\
\hline 1:10 & 10 & $1,64 \pm 0,036$ & $16,39 \pm 0,36$ & $0,0243 \pm 2 \cdot 10^{-4}$ & $0,243 \pm 0,002$ \\
\hline $1: 15$ & 6,67 & $1,11 \pm 0,024$ & $16,67 \pm 0,36$ & $0,0162 \pm 10^{-4}$ & $0,244 \pm 0,001$ \\
\hline $1: 20$ & 5 & $0,84 \pm 0,052$ & $16,78 \pm 1,04$ & $0,0123 \pm 10^{-4}$ & $0,246 \pm 0,001$ \\
\hline
\end{tabular}
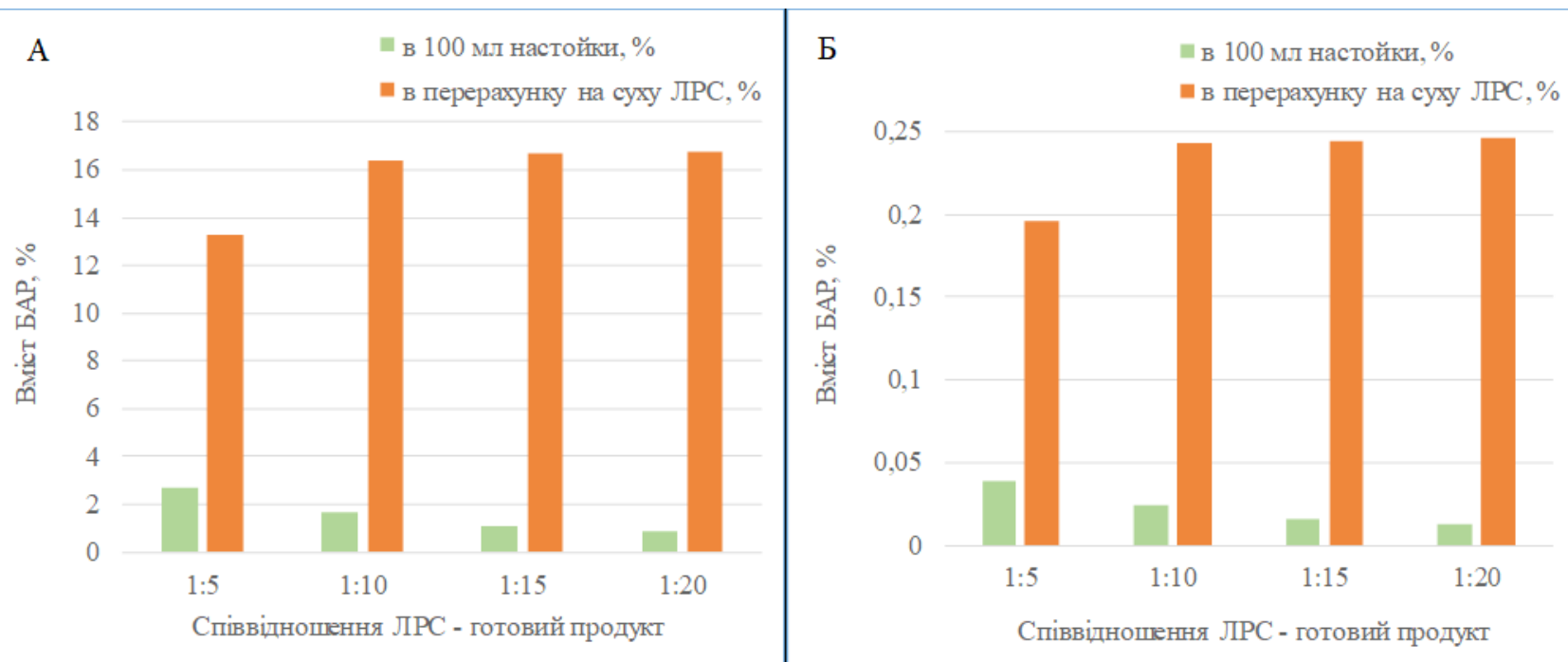

Рис. 1. Динаміка екстрагування БАР залежно від співвідношення ЛРС - готовий продукт: А - вміст екстрактивних речовин; В - вміст ГКК.

вин та концентрація ГКК у настойці. Проте при перерахунку на суху ЛРС ефективність екстракції зростає із збільшенням об'єму екстрагенту. Так, при співвідношенні 1:5 вміст суми вилучених БАР та ГКК складав близько 13,3 \% та 0,196 \% відповідно, а використання співвідношення 1:10 дозволило більш повно виснажити сировину з показниками 16,4 \% та 0,243 \% відповідно. Наступне збільшення об'єму етанолу незначно підвищило вихід сухого залишку та ГКК. При порівнянні співвідношень 1:10 та 1:20 вихід суми БАР збільшився на 0,4 \%, а для ГКК - на 0,02 \%.

Отже, враховуючи концентрацію БАР у настойці та ефективність вилучення екстрактивних речовин і ГКК із ЛРС, ми обрали співвідношення сировини до готового продукту 1:10.

Відомо, що поверхня розділу фраз «тверда ЛРС - екстрагент» зростає із зменшенням розміру частинок сировини. Відповідно, переважно спостеріга- ється залежність, яка полягає у збільшенні ефективності вилучення БАР для подрібненої ЛРС. Проте при надмірному подрібненні із сировини додатково екстрагуються баластні речовини, в тому числі слизи, які при набуханні сповільнюють процес екстракції [8]. Тому на наступному етапі експерименту вивчали вплив ступеня подрібнення ЛРС на відсоток вилучення БАР. Зразки настойок готували на $40 \%$ етанолі методом мацерації та в співвідношенні 1:10. Результати визначення залежності вмісту БАР від ступеня подрібнення ЛРС представлені в таблиці 2.

Отримані дані дослідження свідчать про незначний вплив ступеня подрібнення ЛРС фрітокомпозиції на процес екстракції БАР. Розбіжність у отриманих результатах зразків при виході екстрактивних речовин складає $(0,04 \pm 0,01) \%$, ГКК - $(0,01 \pm 0,01)$ \%. Динаміка збережена. Всі рослини фрітокомпози-

Таблиця 2. Залежність виходу екстрактивних речовин та ГКК від ступеня подрібнення ЛРС

\begin{tabular}{|l|c|c|}
\hline \multicolumn{1}{|c|}{ Ступінь подрібнення ЛРС } & $\begin{array}{c}\text { Сухий залишок у 100 мл } \\
\text { настойки, \% }\end{array}$ & $\begin{array}{c}\text { Вміст ГКК у перерахунку на суху } \\
\text { ЛРС, \% }\end{array}$ \\
\hline Зразок № 1 (не просіяна ЛРС) & $1,639 \pm 0,036$ & $0,243 \pm 0,002$ \\
\hline Зразок № 2 (5 і більше мм) & $1,633 \pm 0,036$ & $0,239 \pm 0,001$ \\
\hline Зразок № 3 (3-4 мм) & $1,644 \pm 0,032$ & $0,247 \pm 0,002$ \\
\hline Зразок № 4 (0-2 мм) & $1,531 \pm 0,025$ & $0,228 \pm 0,001$ \\
\hline
\end{tabular}

ISSN 2312-0967. Фармацевтичний часопис. 2018. № 1 
ції мають однакову ЛРС (листя), яка у висушеному стані достатньо крихка, особливо в кропиви дводомної, легко та довільно подрібнюється при завантаженні до лабораторного екстрактора. Тому для економного використання ЛРС ми обрали фрітокомпозицію з подрібненою сировиною без процесу просіювання.

Процес екстрагування БАР з ЛРС потребує значних затрат часу, необхідного для проникнення екстрагенту через рослинну клітинну стінку, розчинення речовин в середині клітини та вивільнення БАР в навколишнє середовище. Проте надмірна тривалість екстрагування збільшує відсоток виходу баластних речовин, які за рахунок великої молекулярної маси вилучаються пізніше основних низькомолекулярних БАР. Відповідно, занадто тривале екстрагування погіршує якість готової витяжки, а також економічно недоцільне. Тому наступний етап дослідження полягав у вивченні динаміки вилучення БАР із фрітокомпозиції 3 метою встановлення балансу часу. Результати дослідження залежності вмісту екстрактивних речовин та ГКК від часу екстрагування представлені в таблиці 3.

Результати досліджень показали, що найбільш інтенсивне вивільнення БАР відбувалось протягом першої доби екстрагування; продовження часу екстрагування до 2 діб дещо підвищило відсоток вилучення екстрактивних речовин та ГКК; настоювання ЛРС протягом 3 та 7 діб не мало суттєвого впливу на зростання відсотку БАР у досліджуваних зразках. Відповідно, недоцільним є час настоювання 7 діб, який є стандартним для процесу мацерації. Враховуючи представлені дані експерименту, рекомендований сумарний час настоювання - не довше 3-х діб.

На завершальному етапі ми вивчали вплив методу екстракції на ступінь вивільнення БАР із ЛРС. У дослідженні використали найбільш поширені методи
Фармацевтична технологія, біофармація, гомеопатія Pharmaceutical technology, biopharmacy, homeopathy одержання витяжок в технології настойок, а саме мацерацію, ремацерацію (дробову мацерацію) та перколяцію. Враховуючи об'єм етанолу та ефективність затрат часу на екстрагування, проводили трикратну ремацерацію по одній добі настоювання зі свіжою порцією екстрагенту. Перколяцію здійснювали в лабораторному перколяторі за стандартних умов: намочування ЛРС - 5 год, настоювання - 2 доби, швидкість проціджування екстрагенту - 1/24 об'єму завантаженого перколятора. Результати випробувань представлені в таблиці 4.

Як свідчать результати досліджень, застосування методів ремацерації та перколяції дозволяє більш повно виснажити ЛРС за двічі менший період часу порівняно зі стандартною мацерацією (триває 7 діб). При перколяції вихід екстрактивних речовин 1,722 \% та ГКК 0,266 \% був незначно вищим порівняно з методом ремацерації - 1,694 \% і 0,263 \% відповідно. Метод перколяції є більш складним в організації виробництва, оскільки вимагає додаткового обладнання на стадії власне перколяції та контролю за швидкістю пропускання чистого екстрагента через шар ЛРС. Враховуючи всі фрактори (вихід БАР, час екстрагування, обладнання та контроль у процесі виробництва) ми обрали метод ремацерації для одержання розроблюваного ЛКЗ.

Отже, в результаті проведених досліджень ми визначили оптимальні технологічні параметри отримання складної настойки «Стимуфіт», а саме: концентрація етанолу - 40 \%, співвідношення ЛРС до готового продукту 1:10, ступінь подрібнення сировини - подрібнена ціла ЛРС, час екстракції - не довше 3-х діб, метод екстрагування - ремацерація.

На основі отриманих даних розроблено технологічну схему процесу виготовлення складної настойки «Стимуфріт» у промислових умовах, яка представлена на рисунку 2.

Таблиця 3. Залежність виходу екстрактивних речовин та ГКК від часу екстракції

\begin{tabular}{|c|c|c|}
\hline Час екстракції & Сухий залишок, \% & Вміст ГКК в перерахунку на суху лРС, \% \\
\hline Зразок № 1 (6 год) & $1,272 \pm 0,036$ & $0,1486 \pm 0,0017$ \\
\hline Зразок № 2 (1 доба) & $1,522 \pm 0,032$ & $0,2128 \pm 0,0017$ \\
\hline Зразок № 3 (2 доби) & $1,633 \pm 0,044$ & $0,2428 \pm 0,0008$ \\
\hline 3разок № 4 (3 доби) & $1,638 \pm 0,040$ & $0,2431 \pm 0,0006$ \\
\hline Зразок № 4 (7 діб) & $1,639 \pm 0,036$ & $0,2434 \pm 0,0018$ \\
\hline
\end{tabular}

Таблиця 4. Залежність виходу екстрактивних речовин та ГКК від методу екстракції

\begin{tabular}{|c|c|c|}
\hline Метод екстракції & Сухий залишок, \% & Вміст ГКК у перерахунку на суху ЛРС, \% \\
\hline Зразок № 1 (мацерація) & $1,639 \pm 0,036$ & $0,243 \pm 0,002$ \\
\hline 3разок № 2 (ремацерація) & $1,694 \pm 0,040$ & $0,263 \pm 0,001$ \\
\hline Зразок № 3 (перколяція) & $1,722 \pm 0,036$ & $0,266 \pm 0,001$ \\
\hline
\end{tabular}

ISSN 2312-0967. Pharmaceutical review. 2018. № 1 
Фармацевтична технологія, біофармація, гомеопатія

Pharmaceutical technology, biopharmacy, homeopathy

\section{Вихідна сировина, Виготовлення настойки проміжні продукти $i$ «Стимуфіт»}

\section{Контроль у прочесі виробництва} матеріали

Листя кропиви дводомної, листя шавлії лікарської, листя каштана кінського

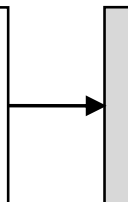

Стадія 1. Подрібнення і змішування ЛРС

Ваги, траворізка, реакторзмішувач

\section{$\downarrow$}

Етанол, вода очищена

Суміш подрібненої сировини зі стадії 1 , екстрагент зі стадії 2

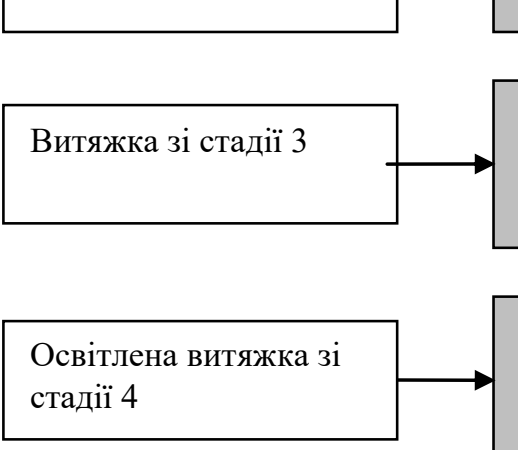

Стадія 2. Підготовка екстрагенту

Мірник, збірник

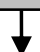

Стадія 3. Настоювання

Екстрактор, мірник, збірник

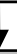

Стадія 4. Відстоювання витяжки

Відстійник, збірник

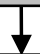

Стадія 5. Фільтрування витяжки

Друк - фільтр
Вхідний контроль сировини, маса сировини

Концентрація спирту, час перемішування, об’єм екстрагента

Об'єм порцій екстрагента, маса сировини, час настоювання, об’ $€$ м витяжки

Температурний режим, час відстоювання

Органолептичні показники, густина витяжки, вміст діючих речовин, сухий залишок, режим роботи друк-фільтра

\section{Пакування настойки}

Очищена настойка зі стадії 5, флакони, етикетки

Флакони із настойкою, листкивкладиші, коробки

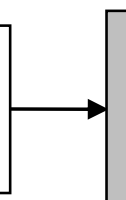

\section{Стадія 6}

Фасування настойки у флакони Пакувальний стіл
Об’єм наповнення, цілісність флакону, правильність друку
Комплектність, правильність друку, цілісність флаконів
Стадія 7

Пакування флаконів у коробки

Пакувальний стіл

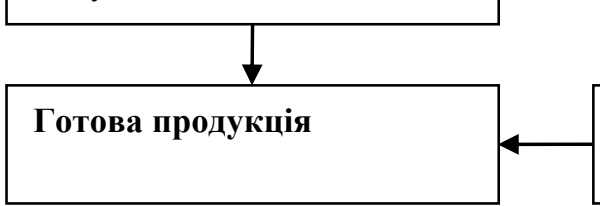

Контроль якості готової продукції

Рис. 2. Технологічна схема виробництва комплексної настойки «Стимуфріт».

ISSN 2312-0967. Фармацевтичний часопис. 2018. № 1 
Фармацевтична технологія, біофармація, гомеопатія

Pharmaceutical technology, biopharmacy, homeopathy

Висновки. 1. Визначені оптимальні технологічні параметри виготовлення складної настойки «Стимуфріт», а саме: концентрація етанолу - 40 \%, співвідношення ЛРС до готового продукту - 1:10, ступінь подрібнення сировини - подрібнена ціла ЛРС, час екс-

тракції - не довше 3-х діб, метод екстрагування - ремацерація.

2. Враховуючи наявність промислового обладнання, розроблено технологію та складено технологічну схему виробництва складної настойки «Стимуфріт» у промислових умовах.

\title{
ИССЛЕДОВАНИЯ ПО РАЗРАБОТКЕ ТЕХНОЛОГИИ НАСТОЙКИ «СТИМУФИТ», ПРЕДНАЗНАЧЕННОЙ ДЛЯ ПРИМЕНЕНИЯ ПРИ ТЕЛОГЕНОВОЙ АЛОПЕЦИИ
}

\author{
М. И. Федоровская ${ }^{1}$, Н. П. Половко ${ }^{2}$ Н. С. Леочко ${ }^{1}$ \\ Ивано-Франковский национальный медицинский университет ${ }^{1}$ \\ Национальный фрармацевтический университет, Харьков² \\ maryana@fedorovska.com
}

Цель работы. Разработка технологии сложной настойки «Стимусрит», предназначенной для накожного применения при телогеновой алопеции.

Материалы и методы. В качестве лекарственного растительного сырья (ЛРС) использовали смесь листья крапивы двудомной - 50 г, листья шалфея лекарственного - 30 г, листья каштана конского - 20 г. Для разработки технологии сложной настойки выбирали оптимальные параметры экстрагирования, а именно: концентрация этанола (20 \%, 40 \%, 70 \%), соотношение сырья и готового продукта (1: 5, 1:10, 1:15, 1:20), степень измельчения сырья (измельченное и непросеянное ЛРС, различные фракции), время (6 часов, 1 день, 2 суток, 3 суток, 7 суток) и метод (мацерация, ремацерация, перколяции) экстракции. Критериями оценки были: выход экстрактивных веществ и количественное содержание гидроксикоричных кислот (ГКК).

Результаты и обсуждение. Экстрагентом избран 40 \% этанол, который хорошо растворяет основные биологически активные вещества и безопасный для накожного применения. Учитывая концентрацию сухого остатка и ГКК в самой настойке, а также в пересчете на сухое сырье (эфффективность истощения ЛРС), обоснована технология сложной настойки, которую получают из измельченной и непросеянной смеси ЛРС в соотношение 1:10 методом трехкратной ремацерации в течение 3 суток.

Выводы. Определены оптимальные технологические параметры изготовления сложной настойки, а именно: концентрация этанола - 40 \%, соотношение ЛРС до готового продукта - 1:10, степень измельчения сырья - измельченное цельное ЛРС, время экстракции - не более 3-х суток, метод экстрагирования - ремацерация. Учитывая полученные результаты, разработана технологическая схема производства сложной настойки «Стимусит» в промышленных условиях.

Ключевые слова: телогеновая алопеция; настойка; крапива двудомная; шалфей лекарственный; каштан конский; технологические параметры.

\section{STUDY ON TECHNOLOGY DEVELOPMENT OF «STIMUPHYT» TINCTURE INTENDED FOR TELOGEN EFFLUVIUM APPLICATION}

\author{
M. I. Fedorovska ${ }^{1}$, N. P. Polovko², N. S. Leochko ${ }^{1}$ \\ Ivano-Frankivsk National Medical University ${ }^{1}$ \\ National Pharmaceutical University, Kharkiv² \\ maryana@fedorovska.com
}

The aim of the work. Technology development of «Stimuphyt» complex tincture which is intended for Telogen effluvium cutaneous treatment.

Materials and Methods. As plant raw materials (PRM) a following mixture was used: Urtica dioica leaves - $50 \mathrm{~g}$, Salvia officinalis leaves - $30 \mathrm{~g}$, Aesculus hyppocastanum leaves - $20 \mathrm{~g}$. Optimal extraction parameters were being chosen for the technology development of the complex tincture, namely: the concentration of ethanol (20\% $40 \%, 70 \%)$, the ratio of PRM and obtained tincture (1:5, 1:10, 1:15, 1:20), sizes of PRM particles (cut and non- sifted PRM, different fractions), time (6 h, 1 day, 2 days, 3 days, 7 days) and the extraction methods (maceration, remaceration, percolation). The yield of dry residues and quantitative content of hydroxycinnamic acids (GCA) were used as the evaluation criteria.

ISSN 2312-0967. Pharmaceutical review. 2018. № 1 
Фармацевтична технологія, біофармація, гомеопатія

Pharmaceutical technology, biopharmacy, homeopathy

Results and Discussion. $40 \%$ ethanol was chosen as an extraction agent, because it dissolves the basic biologically active substances and is safe for cutaneous application. Taking into account the concentration of dry residues and GCA in the tincture and also in the dry PRM (recalculation of PRM extraction efficiency) the complex tincture technology was substantiated. Thus the tincture was obtained from cut and non- sifted mixture of PRM at a 1:10 ratio with the method of triple remaceration for 3 days.

Conclusions. The optimum technological parameters of the complex tincture preparation were determined, namely: the concentration of ethanol $-40 \%$, the ratio of PRM and obtained product $-1: 10$, sizes of PRM particles - cut and non- sifted PRM, extraction time - not longer than 3 days, the method of extraction - remaceration. Considering the obtained results, the technological scheme of «Stimuphyt» complex tincture preparation in industrial conditions was developed.

Key words: Telogen effluvium; tincture; Urtica dioica; Salvia officinalis; Aesculus hyppocastanum; technological parameters.

\section{Список літератури}

1. Галлямова Ю. А. Стратегия и тактика лечения дисрфузного поредения волос / Ю. А. Галлямова // Лечащий врач. - 2012. - № 10. - С. 14-17.

2. Ярема І. О. Маркетингові дослідження ринку лікарських та косметичних засобів призначених для застосування при різних фрормах алопеції / І. О. Ярема, М. І. Федоровська, Л. В. Соколова // Актуальні питання фармацевтичної і медичної науки та практики. - 2014. - № 3 - С. $106-110$.

3. Herbal medicines as an effective therapy in hair loss-Areview / S. M. Patil, G. N. Sapkale, U. S. Surwase, B. T. Bhomble // Research Journal of Pharmaceutical, Biological and Chemical Sciences. - 2010. - Iss.1 - P. 773-781.

4. Kaushik R. Alopecia: herbal remedies / R. Kaushik, D. Gupta, R. Yadav // International journal of pharmaceutical science and research. - 2011. - Iss. 2 (7). - P. 1631-1637. 5. Дослідження активності настойки листя каштана кінського з метою розробки складу лікарських і косметич- них засобів / Л. М. Малоштан, А. О. Башура, Н. П. Половко [та ін.] // Актуальні питання фрармацевтичної і медичної науки та практики. - 2012. - № 1. - С. 71-73. 6. Федоровська М. І. Теоретичне обґрунтування складу комплексної настойки для місцевого застосування при телогеновій алопеції / М. І. Федоровська / Фітотерапія. Часопис. - 2014. - № 3. - С. 73-77.

7. Державна фрармакопея України: в 3 т. // Державне підприємство «Український науковий експертний фрармакопейний центр якості лікарських засобів». - 2-е вид. - Харків : Державне підприємство «Український науковий експертний фрармакопейний центр якості лікарських засобів», 2015. - Т. 1. - 1128 с.

8. Галкін О. Ю. Визначення оптимальних параметрів технології одержання фрітопрепарату для лікування та просрілактики різних фрорм алопеції / О. Ю. Галкін, А. Г. Котов // Фармацевтичний часопис. - 2011. - № 1. - C. 35-38.

\section{References}

1. Halliamova YuA. [The strategy and tactics of treating of diffuse hair thinning]. Lechashch vrach. 2012;10: 17-7. Russian.

2. Yarema IO, Fedorovska MI, Sokolova LV. [Marketing research of medicinal and cosmetic products intended for use in various forms of alopecia]. Aktualni pytannia pharmatsevt med nauky praktyky. 2014;3: 106-10. Ukrainian.

3. Patil SM, Sapkale GN, Surwase US, Bhomble BT. [Herbal medicines as an effective therapy in hair loss - A review]. Res J Pharm Biol Chem Sci. 2010;1: 773-81.

4. Kaushik R, Gupta D, Yadav R. [Alopecia: herbal remedies]. Int J Pharm Sci Res. 2011;2(7): 1631-37.

5. Maloshtan LM, Bashura AO, Polovko NP, Strus OYe. [Investigation of the horse chestnut leaves tincture activity in

order to develop the composition of medicinal and cosmetic products]. Aktualni pytan pharmatsevt med nauky praktyky. 2012;1: 71-3. Ukrainian.

6. Fedorovska MI. [Prospect of medicinal plants application in various forms of alopecia]. Fitoterap chasop. 2014;3: 73-

7. Ukrainian.

7. State Pharmacopoeia of Ukraine: in 3 vol. / State Enterprise «Ukrainian Research Center expert pharmacopoeia quality medicines.» - 2nd ed. - Kharkiv State Enterprise «Ukrainian Research Center expert pharmacopoeia drug quality». 2015; 1: 1128. Ukrainian.

8. Halkin OYu, Kotov AH. [Determination of the optimal parameters of technology of phytopreparation for treatment and prevention of different types of alopecia]. Farmatsevt chasop. 2011;1: 35-8. Ukrainian.

Отримано 07.02.2018 